\title{
ПСИХОЛОГІЧНИЙ АНАЛІЗ ПРОБЛЕМИ САМОПІЗНАННЯ ОСОБИСТОСТІ
}

УДК: 159.923

\section{Камінсъка Олъга Володимирівна}

\begin{abstract}
Доктор психологічних наук, доцент, професор кафедри загальної психології та психодіагностики Рівненського державного гуманітарного університету, м. Рівне (Україна)
\end{abstract}

\begin{abstract}
Анотація. В статті досліджуються різні конщепциї та точки зору на прочес самопізнання, визначається його роль в становленні та розвитку особистості. Значна увага приділяється вивченню ролі самопізнання в прочесі розвитку самосвідомості, а також його впливу на формування «Я-концепції» та самоставлення особистості. Підкреслюється взаємозв'язок самопізнання та рефлексії. Рефлексія аналізується як філософське поняття та психологічна властивість особистості. Досліджуються види рефлексії, їх психологічна сутність та специифіка впливу на формування особистості. Приділяється увага розкриттю особливостей та умов розвитку педагогічної рефлексії. Підкреслюється значення екзистенційної рефлексії у пропрацюванні станів фрустрацїі.
\end{abstract}

Ключові слова: самопізнання, самосвідомість, рефлексія, особистість.

Постановка проблеми. Самопізнання $\epsilon$ важливим механізмом, що забезпечує розвиток самосвідомості, дозволяє особистості сформувати адекватний образ «Я», зрозуміти як іiі оцінюють інші. Проблема самопізнання аналізувалась як вітчизняними так і зарубіжними вченими, які розглядають їі як складний, багатовимірний психолого-філософський феномен, що має неоднозначне трактування. Розуміння психологічних джерел розвитку самопізнання та його ролі у становленні самосвідомості $€$ важливим завданням, що постає сього- дні перед дослідниками.

\section{Аналіз останніх досліджень і публіка-} цій. Зважаючи на актуальність проблеми самопізнання в сучасній науці здійснюються активні спроби дослідити механізми цього феномену, джерела його актуалізації та активізації, а також його психологічну сутність. Такий аналіз здійснюється як у психологічному, так i в філософському напрямках. Зокрема, О. Гріньова [2] підкреслює безпосередній зв'язок самопізнання та рефлексії, пов'язуючи розвиток цих характеристик з ситуацією екзи- 
стенційного вибору, основою якого є рефлексивне осмислення власного «Я» та свого життєвого шляху, вихід за межі конкретного буття та вироблення механізмів суб'єктного управління ним.

В контексті проблеми самопізнання аналізувалась також педагогічна рефлексія, як необхідна умова успішного виконання професійної діяльності (А. А. Бізяєва [1]); налагодження взаємозв'язку між вчителем та учнем (Н. В. Кузьмина [5]); усвідомлення необхідності та напрямків особистісного зростання (Л. М. Мітіна [8]).

Водночас слід відмітити, що позиції щодо аналізу феномену самопізнання $є$ суперечливими та несистематизованими. Враховуючи це метою статті є узагальнення наукових теорій та поглядів на проблему самопізнання.

Виклад основного матеріалу дослідження. Пізнання в цілому - це онтологічна форма буття людини, як специфічного способу існування сутнього. Сутність пізнання, як форми людського буття, полягає у розкритті та присвоєнні сутності пізнаного - в осягненні буття. Процес пізнання починається з безпосереднього сприйняття існування, а потім, через абстрагування та генералізацію сутності, завершується визначенням цього сутнього у категорії, понятті, теорії тощо. Результатом пізнавальної діяльності людини виступає перетворена дійсність, i, таким чином, відбувається взаємопроникнення двох основних форм буття людини - пізнання та діяння [3].
С.Л. Франкл стверджує, що буття людини є самобуттям. Специфічність людського способу існування визначається саме тим, що буття людини, ऑii безпосереднє самобуття, здійснюється "як для-себе-буття, як буття, що собі самому відкривається" [12, с. 97]. Тому пізнання та діяння у дійсності реалізуються як самопізнання та самодіяння.

Самопізнання полягає у забезпеченні саморозвитку людської сутності конкретного індивіда, його особистості, неповторної індивідуальності, людяності. Саморозвиток - це самостійне, спрямоване самою людиною, здійснення індивідуальної сутності свого буття - окремого конкретного людського буття. На цьому шляху необхідним предметом пізнання для людини стає буття iї «Я»- достеменної сутності її власного буття як людського індивіда. Розвиток людини, як правило, і $є$ процес розгортання сутності «Я». Якщо самостійне буття (самобуття) «Я» реальне, то індивід має володіти диференційованими засобами та прийомами безпосереднього чуттєвого пізнання проявів цієї реальності, а також розвинутою здатністю «повертати» зміст свого пізнання предметові самопізнання - «Я». В процесі онтогенезу людина поступово оволодіває необхідним досвідом здійснення самопізнавальних та самоперетворюючих впливів, засвоюючи культурно-історичний досвід та виявляючи індивідуальну здатність знаходити або вибудовувати власні, індивідуальнонеповторні засоби самодіяння [3]. 
Самопізнання включається до самосвідомості в якості одного з основних процесів, що забезпечують його зміст і динаміку. Воно визначається динамічною стороною самосвідомості й лежить в основі іiі функціональних проявів. Саме з такої позиції можна широко розглядати самопізнання, аналізувати його можливості. Існуюча закономірність у співвідношеннях самосвідомості й самопізнання іноді розглядається з протилежних точок зору: у першому варіанті в самопізнанні вбачають умови самосвідомості, у другому - тільки іiі результат. Самопізнання - це процес, розгорнутий у часі, пов'язаний з рухом від одиничних ситуативних образів через їхню інтеграцію в цілісне утворення - в поняття власного «Я» як суб’єкта, відмінного від інших. Цей процес поєднаний 3 переживаннями, які відображаються в емоційно-ціннісному ставленні особистості до себе, де ці переживання закріплюються у відповідну самооцінку і проявляються в саморегуляції особистості. Таким чином, самопізнання - динамічний, якісний, інтегративний процес «Я-концепції» особистості, розгорнутий у часі, спрямований на пізнання себе в якості суб'єкта діяльності та спілкування, який характеризує мотиваційноціннісне ставлення до оволодіння системою знань про себе, свої психофізичні і морфофункціональні можливості, їхнє творче використання для саморозвитку й самовдосконалення [11].

Недостатньо розвинена здатність до самопізнання та недостатній самоінтерес призводять до неповного розуміння власної особистості й нечіткої структури «Я-образу». Низький рівень самоінтересу притаманний людям, які майже не проявляють цікавості до власної особи, мотив самопізнання не актуалізований. Оскільки людині притаманна тенденція до створення і збереження позитивної «Яконцепції», вона усвідомлює та приймає тільки позитивні риси й характеристики, витісняючи негативну інформацію про себе, що призводить до появи неадекватно завищеного самоставлення.

Самопізнання - це також своєрідний механізм пізнавальної діяльності людини, в основі якого лежить процес рефлексії. Рефлексивність мислення та пізнання людини є, власне, здатністю до активного перетворюючого та пізнавального впливу відносно самого себе. Це специфічна для людського способу існування форма пізнавально-орієнтуючої діяльності у світі. Іноді рефлексія визначається як процес розмірковування індивіда над тим, що відбувається в його свідомості. Соціальнопсихологічне визначення рефлексії виглядає як специфічна форма усвідомлення діючим суб'єктом того, як він сприймається та оцінюється іншими індивідами або спільнотами. Можна також говорити про складну рефлективну діяльність свідомості людини, яка є основою самоусвідомлюючих дій, оскільки власне й надає безпосередньо-чуттєвий матеріал для розмірковування над особливостями та озна- 
ками свого внутрішнього світу [4].

Рефлексію можна розглядати як філософський метод, при якому об'єктом пізнання може бути сам спосіб пізнання, а також як знання, думку або вчинок. При цьому виділяють такі види рефлексії: елементарна - аналізує знання та вчинки, їх значення та межі; наукова - орієнтована на критику та осмислення теоретичного знання, а також досліджує прийоми та методи пізнання, які використовуються в тій чи іншій сфері досліджень; філософська - сконцентрована на усвідомлені та осмисленні основ буття, мислення та людської культури загалом. Рефлексія - це унікальна здатність людської свідомості в процесі сприйняття діяльності сприймати й саму себе, внаслідок чого людська свідомість постає як самосвідомість [9].

Рефлексивна свідомість проявляється в осмисленні і переживанні людиною як окремої дії, вчинку, так і смислу буття. Виникнення у людини здатності до рефлексії свідчить про високий рівень ii самосвідомості, готовність не тільки до пізнання самого себе, корекції своєї поведінки, способу життя. Рефлексія виявляється тоді, коли особистість подумки виділяє себе із сфери буття, життєвої ситуації і оцінює в співвідношенні з моральними еталонами. В результаті вона може змінюватися, переоцінюючи минуле задля майбутнього, вступати в діалог з собою, уявним співбесідником [1].

В процесі розвитку людини рефлексив- на свідомість виступає на різних рівнях і в різних формах. Як властивість індивіда рефлексивність є здатністю відображати не лише свій образ «Я», а й усвідомлювати сутність своєї взаємодії з іншими людьми. В сфері міжособистісних взаємин рефлексія виступає важливим компонентом моральності поведінки індивіда. На думку В. А. Роменця [10], це явище післядії, в ньому пояснюється сутність діяння.

Рефлексія розуму, сумління, часто відстає від актів вибору. Акт, дія вибору обумовлюється рішенням волі, післядія - рефлексією, самооцінкою правильності вибору рішення. По суті, самооцінка в цьому випадку виступає як рефлексивне ставлення людини до себе, коли іiі «Я» одночасно є і суб'єктом і об'єктом самоаналізу [7].

Здатність до рефлексії об'єднує функції поведінки та управління людини своїми вчинками. У сучасній науці межі категорії рефлексії істотно розширилися. Крім традиційної, ретроспективної функції рефлексії - критичного аналізу накопиченого наукою знання активно застосовується iї конструктивна, творча функція: розробка цінностей, цілей, програм і самих засобів наукової діяльності. Рефлексія широко використовується не тільки на філософському, але і на загальнонауковому рівні, виступаючи або як методологічний засіб міждисциплінарних розробок, або пояснювальний принцип для деяких соціальних і гуманітарних дисциплін [8].

В психології звертається увага на особ- 
ливості педагогічної рефлексії. Аналіз джерел свідчить про неоднозначність розуміння онтологічних аспектів рефлексії педагога в теоретико-прикладних дослідженнях. Так, у межах структурно-функціонального підходу до аналізу педагогічної діяльності Н. Кузьміна розглядає рефлексію як психічний процес, що обслуговує гностичний, конструктивний, організаційний, комунікативний і проектувальний компоненти діяльності вчителя [5]. Натомість А. Маркова, спираючись на розуміння особистості вчителя як суб'єкта педагогічної діяльності та суб'єкта спілкування, розглядає рефлексію у зв'язку з певними групами педагогічних умінь [6], а Л. Мітіна характеризує педагогічну рефлексію як професійно-значущу властивість особистості, яка входить до групи рефлексивно-перцептивних здібностей вчителя [8]. Цікавим є погляд I. Зимньої, яка пов'язує педагогічну рефлексію з професійною самосвідомістю вчителя як суб'єкта педагогічної діяльності, що несе соціальну відповідальність за виховання та навчання інших людей [3].

Особливої уваги заслуговує підхід до розгляду педагогічної рефлексії, представлений у дослідженнях Ю. Кулюткина. Автор розвиває ідею про необхідність розуміння психологічної структури діяльності вчителя як процесу рефлексивного управління діяльністю учня, головним завданням якого є постанова учня в позицію активного суб'єкта власної діяльності, розвитку в нього здатності до са- моуправління. Процес кооперації діяльності вчителя й учня забезпечує не тільки досягнення спільної мети, але є умовою розвитку саморегуляції та самозміни особистості учня та вчителя [9].

3 позиції метапідходу до розуміння природи педагогічної діяльності, рефлексія та рефлексивні процеси включені в усі іiї компоненти. Вони виявляються: у розробці предметного змісту діяльності учнів, що потребує, 3 одного боку, визначення змісту навчального матеріалу, з іншого - відображення вікових та індивідуальних особливостей його сприймання та засвоєння учнями; побудови форм спільної діяльності під час опанування основними дидактичними завданнями; усвідомлення педагогом власної діяльності, коли сама діяльність виступає для вчителя як спеціальний предмет аналізу, осмислення та оцінки. При цьому необхідність рефлексивного ставлення до власної діяльності викликана тим, що індивідуальна діяльність вчителя набуває результативності лише в загальній системі навчально-виховної роботи школи як соціального інституту. Отже, педагогічна рефлексія вчителя забезпечує як об'єктивацію власного досвіду, так і розуміння досвіду інших [6].

Найвищим рівнем розвитку рефлексії $\epsilon$ екзистенційна рефлексія, яка забезпечує осмислення людиною не окремих аспектів свого життєвого поля, а життя у цілому, в тому числі його ключових ціннісно-смислових конструктів. Рефлексія, зокрема екзистенційна, 
детермінує активізацію смисложиттєвого пошуку, ціннісних і смисложиттєвих орієнтацій особистості у критичні або лімінальні періоди iii життя. На лімінальних етапах життєвого шляху після логічного завершення певної частини життєвої історії людини саме творення особистістю власних екзистенцій свого буття сприяє виробленню нею перспективного проекту самоздійснення на наступному життєвому етапі. Рефлексивне осмислення і подальше творення людиною авторського життєвого проекту визначає інтеграцію їі життєвої активності у різних сферах буття й концентрацію життєвої енергії на досягненні стратегічних життєвих цілей [2].

Висновок. Процес самопізнання нерозривно пов'язаний з рефлексією, яку можна розглядати в широкому розумінні - як філософську категорію, та в вузькому - як властивість особистості, що дозволяє їй об'єктивно оцінити себе, сформувати адекватне самоставлення та самооцінку. Проблема самопізнання досліджується багатьма вченими, кожен з яких акцентує увагу на іï окремих особливостях, однак всі вони стверджують, що самопізнання $\epsilon$ механізмом розвитку самосвідомості, що $\epsilon$ необхідною умовою становлення особистості, формування іiї індивідуальності.

Огляд підходів до розуміння явища самопізнання у психологічній науці дозволяє здійснити певні узагальнення. Самопізнання розглядається як механізм розвитку самосвідомості, що дозволяє відображувати успіхи та труднощі в процесі аналізу як власної особистості в цілому, так і результатів конкретної діяльності, успішність чи неуспішність поведінкових та соціальних актів. Цей механізм активується внаслідок появи внутрішніх конфліктів, незадоволеності особистістю своїм положенням в групі чи в соціумі, ситуацій фрустрації та переживання когнітивного дисонансу, що призводить до зміни позиції особистості до себе як суб'єкта пізнання, діяльності й спілкування. Продуктом самопізнання є пошук і створення особистістю нових уявлень про себе, розширення «Я-концепції», надання ій чіткості, позбавлення від уявлень, що не узгоджуються між собою. Результатом цього процесу є особистісне зростання та самоприйняття.

Перспективним напрямком дослідження $є$ здійснення подальшого аналізу проблеми самопізнання в межах наукових концепцій філософів і психологів.

\section{Перелік використаних джерел:}

1. Бизяева A. А. Психология думающего учителя: Педагогическая рефлексия / А.А. Бизяева. - Псков: ПГПИ им.С.М.Кирова, 2004. - 216 с.

2. Гріньова О. Вплив рефлексії на проектування життєвого шляху особистості / О. Гріньова // Педагогіка і психологія професійної освіти. - 2016. - № 4. - С.12-15.

3. Зимняя И. А. Педагогическая психология : учеб. для вузов / И. А. Зимняя. - М.: Логос, 2007. - 383 с.

4. Киричук О. Основи психології / О. Киричук. - К.: Либідь, 2006. - 632 с.

5. Кузьмина Н. В. Профессионализм личности препода- 
вателя и мастера производственного обучения / Н.В. Кузьмина. - М. : Педагогика, 2009. - 119 с.

6. Маркова A. К. Психология труда учителя / А.К. Маркова. - М. : Просвещение, 2003. - 192 с.

7. Мирошник О. Педагогічна рефлексія як чинник вияву творчого потенціалу особистості вчителя / О. Мирошник // Естетика і етика педагогічної дії: Збірник наукових праць. - 2011. - Вип. 2. - С. 22-25.

8. Митина Л. М. Психология труда и профессионального развития учителя / Л.М. Митина. - М. : Логос, 2004. $-320 \mathrm{c}$.

9. Мышление учителя: Личностные механизмы и понятийный аппарат / Под ред. Ю.Н. Кулюткина, Г.С. Сухобской. - М. : Педагогика, 2007. - 104 с.

10. Роменець В. А. Історія психології: Стародавній світ. Середні віки. Відродження: Навч. посібник./ В.А. Романець. - К.: Либідь, 2005. - 916 с.

11. Сивохоп E. M. Самопізнання як динамічний, інтегративний процес Я-концепції особистості / Е.М. Сивохоп, I.I. Маріонда // Науковий вісник Ужгородського національного університету. - 2015. - Вип. 7. - С. 1417.

12. Франкл В. Человек в поисках смысла: Сборник. М.: Прогресс, 2006. - 312 с.

\section{References (Transliteration):}

1. Byziaeva A. A. Psykholohyia dumaiushcheho uchytelia: Pedahohycheskaia refleksyia / A.A. Byziaeva. - Pskov: PHPY ym.S.M.Kyrova, 2004. - 216 s.

2. Hrinova $O$. Vplyv refleksii na proektuvannia zhyttievoho shliakhu osobystosti / O. Hrinova // Pedahohika i psykholohiia profesiinoi osvity. - 2016. - № 4. - S.12-15.

3. Zymniaia $Y$. A. Pedahohycheskaia psykholohyia : ucheb. dlia vuzov / Y.A. Zymniaia. - M.: Lohos, 2007. - 383 s.

4. Kyrychuk O. Osnovy psykholohii / O. Kyrychuk. - K.: Lybid, 2006. - $632 \mathrm{~s}$.

5. Kuzmyna N. $\quad$. Professyonalyzm lychnosty prepodavatelia y mastera proyzvodstvennoho obuchenyia / N.V. Kuzmyna. - M. : Pedahohyka, 2009. - 119 s.
6. Markova A. K. Psykholohyia truda uchytelia / A.K. Markova. - M. : Prosveshchenye, 2003. - 192 s.

7. Myroshnyk O. Pedahohichna refleksiia yak chynnyk vyiavu tvorchoho potentsialu osobystosti vchytelia / O. Myroshnyk // Estetyka i etyka pedahohichnoi dii: Zbirnyk naukovykh prats. - 2011. - Vyp. 2. - S. 22-25.

8. Mytyna L. M. Psykholohyia truda y professyonalnoho razvytyia uchytelia / L.M. Mytyna. - M. : Lohos, 2004. $320 \mathrm{~s}$.

9. Mushlenye uchytelia: Lychnostnue mekhanyzmu y poniatyinui apparat / Pod red. Yu.N. Kuliutkyna, H.S. Sukhobskoi. - M. : Pedahohyka, 2007. - 104 s.

10. Romenets $V$. A. Istoriia psykholohii: Starodavnii svit. Seredni viky. Vidrodzhennia: Navch. posibnyk./ V.A. Romanets. - K.: Lybid, 2005. - 916 s.

11. Syvokhop E. M. Samopiznannia yak dynamichnyi, intehratyvnyi protses Ya-kontseptsii osobystosti / E.M. Syvokhop, I.I. Marionda // Naukovyi visnyk Uzhhorodskoho natsionalnoho universytetu. - 2015. - Vyp. 7. - S. 14-17.

12. Frankl V. Chelovek v poyskakh smbsla: Sbornyk. M.: Prohress, 2006. -312 s.

\section{Kaminska Olga}

Doctor of Psychological Sciences, associate professor, assistant professor of general psychology and psychodiagnostics, Rivne State Humanitarian University, Rivne (Ukraine)

\section{PSYCHOLOGICAL ANALYSIS OF SELF-KNOWLEDGE PROBLEM}

\section{ABSTRACT}

The article explores different concepts and points of view on the process of selfknowledge, determines its role in the formation and development of personality. The purpose of the article is to generalize scientific theories and views on the problem of self-knowledge. Much 
attention is paid to the study of the role of selfknowledge in the process of development of selfconsciousness, as well as its influence on the formation of the «I-concept» and self-pacing personality. Self-knowledge is an important mechanism that ensures the development of self-awareness, allows the individual to form an adequate image of «I» to understand how it is appreciated by others. Emphasizes the relationship of selfknowledge and reflection. Reflection is analyzed as a philosophical concept and a psychological property of an individual. The types of reflection, their psychological essence and the specifics of influence on the formation of the personality are studied. The attention is paid to the disclosure of the peculiarities and conditions of the development of pedagogical reflection. Emphasis is placed on the value of existential reflection in the development of frustration states. Attention is drawn to the fact that the process of selfknowledge is inextricably linked with reflection, which can be considered in the broad sense - as a philosophical category, and in the narrow one - as a property of the individual, which allows it to objectively evaluate itself, to form an adequate self-assessment and self-esteem. The problem of self-knowledge is studied by many scholars, each of which focuses attention on its specific features, but they all claim that self-knowledge is a mechanism for the development of self-consciousness, which is a prerequisite for the formation of the individual, the formation of his individuality. Self -knowledge is considered as a mechanism for the development of self-consciousness, which allows to reflect successes and difficulties in the process of analysis of both their own personality as a whole, and the results of concrete activities, the success or failure of behavioral and social acts. This mechanism is activated as a result of the appearance of internal conflicts, the dissatisfaction with the personality of his position in the group or in society, the situations of frustration and the experience of cognitive dissonance, which leads to a change in the position of the individual to himself as a subject of knowledge, activity and communication. The product of self-knowledge is the search and creation of personality of new ideas about oneself, the expansion of the «Iconcept», giving it a clearness, getting rid of ideas that are not consistent with each other. The result of this process is personal growth and selfperception.

Key words: self-knowledge, selfconsciousness, reflection, personality.

\section{Каминская Ольга Владимировна}

Доктор психологических наук, доцент, профессор кафедры общей психологии и психодиагностики Ровенского государственного гуманитарного университета (2. Ровно, Украина)

\section{ПСИХОЛОГИЧЕСКИЙ АНАЛИЗ ПРОБЛЕМЫ САМОПОЗНАНИЯ ЛИЧНОСТИ}

Аннотация. В статье исследуются различные концепции и точки зрения на процесс самопознания, определяется его роль в становлении и развитии личности. Целью статьи 
является обобщение научных теорий и взглядов на проблему самопознания. Значительное внимание уделяется изучению роли самопознания в процессе развития самосознания, а также его влияния на формирование «Яконцепции» и самоотношения личности. Самопознание является важным механизмом, обеспечивающим развитие самосознания, позволяет личности сформировать адекватный образ «Я», понять как его оценивают другие. Подчеркивается взаимосвязь самопознания и рефлексии. Рефлексия анализируется как философское понятие и психологическое свойство личности. Исследуются виды рефлексии, их психологическая сущность и специфика влияния на формирование личности. Уделяется внимание раскрытию особенностей и условий развития педагогической рефлексии. Подчеркивается значение экзистенциальной рефлексии в проработке состояний фрустрации. Обращается внимание на то, что процесс самопознания неразрывно связан с рефлексией, которую можно рассматривать в широком смысле - как философскую категорию, и в узком - как свойство личности, что позволяет ей объективно оценить себя, сформировать адекватное самоотношение и самооценку. Проблема самопознания исследуется многими учеными, каждый из которых акцентирует внимание на ее отдельных особенностях, однако все они утверждают, что самопознание является механизмом развития самосознания, необходимым условием становления личности, формирования ее индивидуальности. Самопознание рас- сматривается как механизм развития самосознания, позволяет отображать успехи и трудности в процессе анализа как собственной личности в целом, так и результатов конкретной деятельности, успешности или неуспешности поведенческих и социальных актов. Этот механизм активируется вследствие появления внутренних конфликтов, неудовлетворенности личностью своим положением в группе или в социуме, ситуаций фрустрации и переживания когнитивного диссонанса, что приводит к изменению позиции личности к себе как субъекта познания, деятельности и общения. Продуктом самопознания является поиск и создание личностью новых представлений о себе, расширение «Я-концепции», предоставление ей четкости, избавление от представлений, которые не согласовываются между собой. Результатом этого процесса является личностный рост и самопринятие.

Ключевье слова: самопознание, самосознание, рефлексия, личность.

Дата отримання статті: 17.10.2017 Дата рекомендації до друку: 19.10.2017 